Федоренко Раїса

кандидат психологічних наук, доцент кафедри практичної та клінічної психології Східноєвропейського національного університету імені Лесі Українки

Фенина Оксана

кандидат психологічних наук, доцент кафедри практичної та клінічної психології Східноєвропейського національного університету імені Лесі Українки http://orcid.org/0000-0003-0171-285 DOI https://doi.org/10.35619/prap_rv.vi14.171

\title{
ПСИХОЛОГІЧНІ ОСОБЛИВОСТІ ОСОБИСТОСТІ, ПОТЕРПІЛОЇ ВІД СЕКСУАЛЬНОГО НАСИЛЬСТВА
}

\begin{abstract}
Анотація. В статті висвітлена проблема потерпілих від сексуального насильства, яка привертає пильну увагу криміналістів, судових медиків, психологів та представників ряду інших областей соціальних знань. У зв'язку з изим переконливим виглядає теза Сахарова про те, щзо визначальну роль в етіології злочинної поведінки відіграє не соиіальне середовище, а особистість, іï індивідуальні психофізичні якості та особливості. Це може бути застосована не лише до злочиния, але й до «винної» в морально-етичному аспекті особистості, до поведінки жертви насильства. Однак $i$ в кримінології згвалтування не піддається серйозним комплексним дослідженням із залученням сочіології $i$ психології. Основна увага, переважно, направлено на вивчення ситуації насильства, особистості гвалтівника, причин, щуо спонукали його скоїти злочин. Всі дослідження жертв сексуального насильства (ЖСН) зводяться до віктимології, тобто до питання про те, як поведінка і психологічні характеристики жертви вплинули на розвиток $i$ результат кримінальної ситуаџї. Таким чином, в дослідженнях кримінології переважає погляд на ЖСН, як на другорядного учасника подій, як на об'єкт. Різкий підйом чисельності згвалтувань, щз відзначається в останні роки як в нашій краӥні, так $і$ в ряді зарубіжних країн, збігся за часом з глибокими сочіально-економічними змінами, зростанням агресивних тенденщій в суспільстві, зміною культурних норм, в тому числі і в сфері сексуальних відносин. Це змушує більш детально дослідити зазначену проблему.
\end{abstract}

Ключові слова: особистість, жертва, злочинещь, злочин, сексуальне насильство.

Постановка проблеми. До недавнього часу у вітчизняних дослідженнях посттравматичного стресового розладу (ПТСР) основна увага приділялася особам, що стали жертвами масових катастроф (війни, землетруси). Однак не менш важлива і масштабна проблема психологічні наслідки унікального травматичного досвіду, такого, як згвалтування (Малкіна-Пих, 2019). Актуальність і значимість досліджень, присвячених вивченню психологічних особливостей особистості, яка потерпіла від сексуального насильства, визначається як теоретичною нерозробленістю даної проблеми у вітчизняній психології, так і необхідністю кваліфікованої допомоги жертвам згвалтування, яка полягає в їх психологічній реабілітації та соціальній реадаптації.

Аналіз останніх досліджень 3 проблеми. Жертви злочину і їх взаємини зі злочинцем розглядаються в роботах Франкла, Мінської, Кузнєцова, Центрова, Вандишева, Коновалова, Антоняна, Голубєва, Кудрякова, Рівмана, Ткаченко, Малкіної-Пих, Мельника, Мушкевич.

Науковий інтерес до цієї проблеми продемонстрований в дослідженнях Васільєва, який, займається юридичною психологією. Його експерименти з вивчення особистості неповнолітніх, які постраждали від сексуального насильства, привертають особливу увагу (Берн, 2004). Деякі питання даної проблеми викладені в наукових роботах Дьяченко, Елемісова, Мамайчук.

Мета статті: виявити фактори і умови поведінки особистості, яка постраждала від сексуального насильства. 
Виклад основного матеріалу дослідження. Експериментальне дослідження особистісних якостей потерпілих від сексуального насильства проводилося нами в Кризовому центрі ЦССМ м. Луцька. Вибірку дослідження склали 27 осіб.

Соціально-демографічна характеристика досліджуваних наступною: всі опитані були неодружені; віковий діапазон - 16-18 років; 65\% респондентів виховуються в повній сім'ї, 35\% - в неповній родині; 77\% - в середньодітній, 23\% - в родині з однією дитиною. Всі повністю здорові, без складних травм і хвороб в дитинстві. 54\% дівчаток до того, що сталося зустрічалися 3 юнаками, 46\% не зустрічалися з юнаками, 79\% мали сексуальний досвід, 21\% не мали, 36\% жертв в момент насильства перебували в нетверезому стані.

3 метою з'ясування обставин насильства нами проводилася бесіда 3 потерпілими, вивчалася кримінальна справу. Аналіз обставин вчинення насильства показав наступні результати: $28 \%-$ опитуваних виявилися випадковими жертвами насильства; $26 \%-3$ числа певної вибірки знали і раніше гвалтівників; 46\% - познайомилися і «допустили наївність», погодившись на зустріч.

Лише 33\% опитаних намагалися чинити опір, а $67 \%$ - опору не чинили.

Для вивчення особистості потерпілих проводилися проективні методики «Неіснуюча тварина», «Написання казки», особистісні опитувальники Кеттелла, FPI. Аналіз результатів проведеного дослідження за методикою «Написання казки» (яка дозволила визначити два аспекти життєвого сценарію: двосторонню позицію і тип сценарної поведінки) дав можливість виявити закономірну схему: початок казок у всіх випробовуваних однаковий, кінець - щасливий. Заслуговує на увагу, середня, кульмінаційна, частина казки, яка у кожного випробуваного різна, що позначає спрямованість казки, способи подолання перешкод і т.д.

Крім виявлення основних позицій, у респондентів також простежується тип сценарної поведінки: Переможець, Непереможець, Невдаха (Берн, 2004). У більшості ЖСН (73\%) домінує тип сценарної поведінки - «Невдаха», що говорить про таку поведінку особистості, як відмова від активного життя, сильний вплив батьківської сім'ї на подальше життя, безнадія, песимістичні погляди. Для $27 \%$ опитаних характерний тип сценарної поведінки «Непереможець». Їм притаманні безнадійність, безперспективність, малорухливість, неактивність. Хоча їм і вдається домогтися якогось результату, вони сумніваються, чи будуть щасливі. Аналізуючи дані, отримані після проведення інших методик, у всіх постраждалих яскраво виражена потреба в спілкуванні i постійна готовність до задоволення цієї потреби. Аналіз малюнків: (методика «Неіснуюча тварина») видно наступне: у 77\% чітко проявляється внутрішньоособистісний конфлікт, йде боротьба мотивів; (Зображення тварини має дві голови). 89\% - зацікавлені в інформації. Значну роль відіграє значимість думки про себе (у тварини великі вуха), 74\% переживають страх, побоювання, недовіру. Більшість респонденток (65\%) характеризуються легковажністю, несерйозністю, непродуманістю дій, 18\% - грунтовністю, обдуманістю, раціональністю в ухвалення рішень. Аналіз малюнків показав, що 93\% згвалтованих орієнтовані на свою сексуальну роль, чуттєвість, підкреслення статі.

Аналіз результатів даних, отриманих за опитувальником Кеттелла, засвідчив, що у 44\% опитуваних - виявлений середній рівень розвитку інтелекту, у $35 \%$ - низький, лише $21 \%$ досліджуваних продемонстрували високі показники за шкалою інтелекту. Для 46\% зазначеної вибірки характерні низька толерантність по відношенню до фрустрації, схильність до почуттів, мінливість інтересів, схильність до лабільності настрою, дратівливість, стомленість, невротичні симптоми. Всього лише $28 \%$ досліджуваних властива емоційна стійкість, витриманість, реалістичний настрій, відсутність нервового стомлення. У значної частини досліджуваних (46\%) високі показники по фактору схильності почуттям, неорганізованості, безвідповідальності, гнучкості відносин до соціальних норм. I лише 28\% ЖСН характеризуються розсудливістю, обережністю, розсудливістю. Їм властиво все ускладнювати, деяка стурбованість, песимізм в сприйнятті дійсності, занепокоєння про майбутнє. У більшості опитуваних (74\%) виявлені високі оцінки з соціальної сміливості, активності, готовності мати справу з незнайомими обставинами i людьми. Помітна схильність до ризику, вміння триматися вільно, розгальмовано. Для $30 \%$ згвалтованих властива мужність, самовпевненість, розсудливість, реалістичність суджень, практичність. Більшість (70\%) досліджуваних виявляють м'якість, стійкість, залежність, прагнення до заступництва, схильність до романтизму, жіночність. 
Майже всі респонденти (88\%) характеризуються відвертістю, довірливістю, доброзичливістю до інших людей, терпимістю, лагідністю, розвиненою уявою, безпосередністю поведінки, природністю, наївністю. Більшість згвалтованих відзначаються тривожністю, депресивністю, ранимістю, вразливістю, лише $28 \%$ - упевнені в собі, холоднокровні, безтурботні. Всього у 26\% відсутня ініціатива прийняття рішень, 46\% потребують схвалення і підтримки інших людей.

При аналізі самоконтролю виявилося, що 74\% випробовуваних недисципліновані, внутрішньо конфліктні, і тільки у $28 \%$ - розвинений самоконтроль, добре контролюють свої емоції і поведінку. Результати дослідження виявили також, що серед тих жертв сексуального насильства, які знали насильника, 26\% властива низька мотивація, лінь, зайва задоволеність і незворушність. Ті жертви, які познайомилися і зважилися на зустріч, 46\% характерна висока напруженість, фрустрованість, наявність збудження та занепокоєння, підвищена мотивація. Важливим регулятором поведінки особистості $\epsilon$ рівень розвитку іï самооцінки. В результаті аналізу було виділено 10 дівчаток (37\%) з неадекватною самооцінкою. У дівчаток із завищеною самооцінкою (15\%) переважали позитивні характеристики образу Я, спостерігалася некритичність, тенденція брати на себе вирішення завдань, які перевищують їх можливості, схильність до ризику. У процесі слідства у них спостерігається розчарування, прагнення перекласти відповідальність за те, що трапилося на інших, на обставини. В процесі психологічного дослідження жертви важливим $\epsilon$ аналіз ії ціннісних орієнтацій. У постраждалих з неадекватною самооцінкою ціннісні орієнтації $є$ нестійкою системою. У деяких 3 них отримані дані співпадали 3 низькими показниками за фактором опитувальника Кеттела, що відображає несумлінність, нестійкість моральних принципів.

Результати, отримані в ході характеристики індивідуально-типологічних особливостей особистості постраждалих від сексуального насильства (опитувальник FPI), дають наступні твердження: за шкалою невротичності набрані високі оцінки у 74\% досліджуваних. Це відповідає вираженому невротичному синдрому астенічного типу із значними психосоматичними порушеннями. При дослідженні спонтанної агресивності, яка дозволяє виявити і оцінити психопатизація інтратенсивного типу, виявилося, що $26 \%$ набрали високі оцінки, які свідчать про підвищений рівень психопатизації, що створює передумови для імпульсивної поведінки. Більшість згвалтованих (80\%) дали високі оцінки за шкалою депресивності. Їм притаманний депресивний синдром в емоційному стані, в поведінці, у відношенні до себе і до соціального середовища. Для 46\% випробовуваних характерний нестійкий емоційний стан зі схильністю до афективного реагування. Виходячи з аналізу отриманих результатів, слід зазначити, що у респондентів погана захищеність до впливу стрес-факторів звичайних життєвих ситуацій, невпевненість в собі. При цьому, не виявлено агресивного ставлення до соціального оточення і вираженого прагнення до домінування. У більшості (74\%) жертв спостерігається схильність до стресового реагування на звичайні життєві ситуації, які протікають оборонно-пасивному типу. 78\% обстежуваних прагнуть до довірливо-відвертої взаємодії з оточуючими людьми при високому рівні самокритичності. Важливо відзначити, що 72\% опитуваних відносяться до екстравертованого типу. Вони схильні приписувати причини події, що трапилася зовнішнім чинникам (долі, випадку), їм притаманний зовнішній контроль. $28 \%$ - інтроверти, вони приймають відповідальність за події, що відбуваються у їх житті на себе, пояснюють все своєю поведінкою, характером, рисами. Ці люди мають внутрішній контроль. Виходячи з особливостей їх особистості, можна виявити причини поведінки жертви в складній ситуації. Багатьом (74\%) згвалтованим притаманний нестійкий емоційний стан, що виявляється в частих коливаннях настрою, підвищеній збудливості, дратівливості, недостатній саморегуляції. У $34 \%$ обстежуваних психічна діяльність протікає переважно за чоловічим типом, у $66 \%$ - за жіночим. Аналіз поведінки жертви вимагає співвідношення виявлених особистісних характеристик зі структурою об'єктивної ситуації, що сталася.

Проведене нами дослідження базувалося на виявленні особистісних якостей постраждалих від сексуального насильства та взаємозалежності від них поведінки жертви. Виявилося в момент бесіди, що лише деякі (28\%) із згвалтованих були випадковими жертвами, які не знали гвалтівників і в момент насильства намагалися чинити опір. 26\% були раніше знайомі, 
спілкувалися 3 насильником певний час і 46\% склали ті, які познайомилися і погодилися на зустріч. Всім опитаним властиві такі якості, як товариськість і постійна потреба в цьому. Вони орієнтовані на свою сексуальну роль, чуттєвість, підкреслення статі. У них переважає депресивний стан, очікування допомоги і підтримки від когось іншого, відвертість, довірливість, доброзичливість до інших людей, терпимість, товариськість. Явно у всіх виражений невротичний синдром астенічного типу.

Першій групі, яку склали випадкові жертви, характерними особливостями є такі риси особистості, як обдуманість, раціональність у прийнятті рішень, витриманість, емоційна стійкість, реалістичний настрій, владність, незалежність, обережність, розвинений самоконтроль.

Другій групі випробовуваних, які були знайомі з гвалтівником до моменту насильства притаманні покірність, лінивість, зайва задоволеність і незворушність, неорганізованість, безвідповідальність. У них відсутня ініціатива прийняття рішень, характерною є низька мотивація.

Більш значима третя група респонденток, які виявили згоду піти на зустріч з малознайомим чоловіком. У них були виявлені такі риси, як несерйозність, непродуманість дій, фрустрованість, схильність почуттям, мінливість інтересів, мінливість настрою, дратівливість, стомлюваність, невротичні симптоми, неорганізованість, гнучкі ставлення до соціальних синдромів, нестійкий емоційний стан.

У досліджуваних другої і третьої груп простежується тип сценарної поведінки як Невдаха, що говорить про сильний вплив батьківської сім'ї на подальше життя, безнадія, песимістичні погляди на життя. У них чітко проявляється внутрішньоособистісний конфлікт, йде боротьба мотивів, велика зацікавленість в інформації, значимість думки про себе, переживають страх, побоювання, недовіру.

У цих групах виявлено легковажне ставлення до оточуючих, невміння враховувати сигнали небезпеки, демонстративність. Вони готові мати справу з незнайомими обставинами і людьми, помітна схильність до ризику, вміння триматися вільно, розгальмовано, наївні і природні. Виходячи з цієї класифікації потерпілих, важливо в процесі судово-психологічної експертизи у справах про згвалтування, щоб психолог враховував ставлення підекспертного до того, що трапилося, особливості прояву психологічного захисту особистості. Останні визначаються індивідуально-психологічними і віковими характеристиками потерпілих.

Висновки і перспективи подальших розвідок. Проведене дослідження i теоретична розробка проблеми, результати яких викладені в нашій статті, дозволили сформулювати деякі найбільш значущі, на наш погляд, висновки, пропозиції та рекомендації. Злочини, що порушують статеву недоторканність і нормальний статевий розвиток дівчат і жінок, представляють особливо велику суспільну небезпеку. Ця небезпека посилюється тим, що неповнолітні, які особливо беззахисні проти статевих зазіхань, часто соромляться повідомити старшим про скоєні стосовно них розпусні дії. Аналіз поведінки жертви вимагає співвідношення виявлених особистісних характеристик зі структурою об’єктивної ситуації того, що трапилося. Вивчення ситуації за матеріалами кримінальної справи, опитувань жертви дає важливу інформацію про поведінку постраждалої, способах іiі захисту. Відповідно до класифікації за характером насильства розподілилися індивідуально-типологічні якості особистості. У всіх досліджуваних підвищена тривожність, почуття страху і боязні, у них погана захищеність до впливу стрес-факторів звичайних життєвих ситуацій, невпевненість в собі. У більшості досліджуваних переважає депресивний стан, очікування допомоги і підтримки від когось іншого. У дівчаток, які були раніше знайомі зі злочинцем, спостерігалася некритичність, тенденція брати на себе вирішення завдань, що перевищують їх можливості, схильність до ризику. У них спостерігається розчарування, прагнення перекласти відповідальність за те, що трапилося на інших, на обставини.

У жертв, які погодилися на зустріч, спостерігалося обмеження активності, невпевненість в своїх силах, високий ступінь психічної напруженості, низький самоконтроль. Ці цифри говорять про дезорганізуючу роль, фрустрованість і тривожність у формуванні адекватності поведінки, що характеризує їх як слухняних, залежних, які не вміють відстоювати свою точку зору. У всіх досліджуваних достовірно домінували незвинувачувальні реакції. Такий тип реакції можна розглядати як своєрідний психологічний захист особистості. У них виявилася тенденція відходу в себе, яка дозволяла послабити включеність в ситуацію, пом'якшити наявний емоційний 
дискомфорт у зв'язку з тим, що трапилося з ними. У постраждалих дівчаток спостерігалася також достовірно низька кількість чітких реакцій в ситуації фрустрації. В основному, у них переважали перешкодно-домінантні реакції, що свідчать про підвищену фіксацію на наявних перешкодах. Дівчата, які стали випадковими жертвами, характеризуються обдуманістю і раціональністю в прийнятті рішень, реалістичним настроєм, владністю, незалежністю, обережністю. У них добре розвинений самоконтроль. Виявлення якостей за такими групами дає можливість передбачити ситуацію, що трапилась і можливість уникнення ii особистістю, що так само можна використовувати в профілактиці злочинів.

Дозвіл психологічних питань поведінки жертви, іiі особистісних особливостей, вимагає всебічного комплексного аналізу 3 виділенням рівня психічної адаптації, стійкості до фрустраційних впливів, самооцінюючого i мотиваційних компонентів особистості, а також ретельного психологічного аналізу ситуації. Це ставить перед експертом-психологом додаткові вимоги: знання процесуального закону, процедури експертного дослідження, знання специфічних умов попереднього слідства і судового розгляду.

\section{СПИСОК ПОСИЛАНЬ}

Антонин, Ю. М., \& Ткаченко, А. А. (1993). Сексуальныле преступления: Чикатило и др. Москва. Безопасность: Насилие в семье. (2018). Взято с http://school3soli.by/uchashchimsya/zdorovyj-obrazzhizni/838-paket-bezopasnosti-nasilie-v-seme.

Берн, Э. (2004). Игры, в которые играют люди. Психология человеческих взаимоотношений. Киев : PSYLIB.

Васильев, В. Л. (2009). Юридическая психология : Учебник. Санкт-Петербург: Питер.

Дерягин, Г. Б., Сидоров, П. И., \& Соловьев, А. Г. (2002). Особенности судебно-медицинской экспертизы при половых преступлениях. Судебно-медицинская экспертиза, 5, 45-49.

Малкина-Пых, И. Г. (2019). Виктимология. Психология поведения жертвы. Взято с http://loveread.ec/read_book.php?id=76575\&p=1

Ромек, В. Г. Конторович, В. А., \& Крукович, Е. И. (2004). Психологическая помощь в кризисных ситуациях. Санкт-Петербург: Речь.

Тарабрина, Н. В. (2001). Практикум по психологии посттравматического стресса. СанктПетербург: Питер.

Харченко, С. В. (2006). Психологическая помощъь пострадавщим в экстремальных ситуащиях. Харьков : Харьковский национальный университет внутренних дел.

\section{REFERENCES}

Antonin, Yu. M., \& Tkachenko, A. A. (1993). Seksualnyye prestupleniya: Chikatilo i dr. [Sexual offenses: Chikatilo et all]. Moskva. [in Russian].

Bezopasnost: Nasiliye $v$ semye [Safety: Domestic Violence]. (2018). Vzyato s http://school3soli.by/uchashchimsya/zdorovyj-obraz-zhizni/838-paket-bezopasnosti-nasilie-vseme. [in Russian].

Bern, E. (2004). Igry. v kotoryye igrayut lyudi [Games People Play]. Psikhologiya chelovecheskikh vzaimootnosheniy. Kyev : PSYLIB. [in Russian].

Vasilyev, V. L. (2009). Yuridicheskaya psikhologiya: Uchebnik [Legal psychology: Tutorial]. SanktPeterburg: Piter. [in Russian].

Deryagin, G. B., Sidorov, P. I. \& Solovyev, A. G. (2002). Osobennosti sudebno-meditsinskoy ekspertizy pri polovykh prestupleniyah [Features of a forensic examination in sexual offenses]. Sudebnomeditsinskaya ekspertiza, 5, 45-49. [in Russian].

Malkina-Pykh, I. G. (2019). Viktimologiya. Psikhologiya povedeniya zhertvy [Victimology. Psychology of victim behavior]. Vzyato s http://loveread.ec/read_book.php?id=76575\&p=1. [in Russian].

Romek, V. G. Kontorovich V. A. \& Krukovich E. I. (2004). Psikhologicheskaya pomoshch v krizisnykh situatsiyakh [Psychological assistance in crisis situations]. Sankt-Peterburg: Rech. [in Russian].

Tarabrina, N. V. (2001). Praktikum po psikhologii posttravmaticheskogo stressa [Workshop on the Psychology of Post-Traumatic Stress]. Sankt-Peterburg: Piter. [in Russian]. 
Kharchenko, S. V. (2006). Psikhologicheskaya pomoshch postradavshim v ekstremalnykh situatsiyakh [Psychological assistance to victims in extreme situations]. Kharkov: Kharkovskiy natsionalnyy universitet vnutrennikh del. [in Russian].

\title{
PSYCHOLOGICAL CHARACTERISTICS OF A PERSON WHO HAS SUFFERED FROM SEXUAL VIOLENCE
}

\author{
Raisa Fedorenko \\ candidate of psychological sciences, associate professor \\ of the department practical and clinical psychology \\ of Eastern European Lesya Ukrainka National University \\ Oksana Fenyna \\ candidate of psychological sciences, associate professor \\ of the department practical and clinical psychology \\ of Eastern European Lesya Ukrainka National University \\ http://orcid.org/0000-0003-0171-285 \\ DOI https://doi.org/10.35619/prap_rv.vi14.171
}

\begin{abstract}
The article considers the problem of victims of sexual violence today attracts the attention of criminologists, forensic doctors, psychologists and representatives of several other areas of social knowledge. In this regard, the thesis of Sakharov that the decisive role in the etiology of criminal behavior is played not by the social environment, but by the personality, its individual psychophysical qualities and features, is convincing. This applies not only to the perpetrator, but also to the "guilty" person in the moral and ethical aspect, to the behavior of the victim of violence. However, in criminology, rape does not lend itself to serious comprehensive research involving sociology and psychology. The main attention, as a rule, is aimed at studying the situation of violence, the identity of the rapist, the reasons that prompted him to commit a crime. All studies of victims of sexual violence come down to victimology, that is, to the question of how the victim's behavior and psychological characteristics influenced the development and outcome of the criminal situation. Thus, in criminology research, the prevailing view is on the victim as a secondary participant in events, as an object.

Until recently, domestic studies of post-traumatic stress disorder focused on individuals who became victims of mass disasters (wars, earthquakes). However, an equally important and large-scale problem is the psychological consequences of a unique traumatic experience, such as rape.

Resolving the psychological issues of the victim's behavior, its personality traits, requires comprehensive analysis with the emphasis on the level of mental adaptation, resistance to frustration, self-esteem and motivational components of the personality, as well as a thorough psychological analysis of the situation. This imposes additional requirements on the expert psychologist: knowledge of the procedural law, procedures for expert research, knowledge of the specific conditions of the preliminary investigation and trial.
\end{abstract}

Keywords: personality, victim, criminal, crime, sexual violence. 